\title{
Candida parapsilosis endocarditis: a comparative review of the literature
}

\author{
C. Garzoni • V. A. Nobre • J. Garbino
}

Published online: 6 September 2007

(C) Springer-Verlag 2007

\begin{abstract}
Fungal endocarditis (FE) is an uncommon disease, and while accounting for only $1.3-6 \%$ of all cases of infectious endocarditis, it carries a high mortality risk. Although Candida albicans represents the main etiology of $\mathrm{FE}, C$. parapsilosis is the most common non-albicans species. We report the case of a 32-year-old man with a history of prior intravenous drug (IVD) use hospitalized with endocarditis due to C. parapsilosis and review all 71 additional cases documented in the literature. A retrospective analysis of the 72 C. parapsilosis cases compared to 52 recently reviewed cases of $C$. albicans endocarditis was conducted to identify organism-specific clinical peculiarities. The most common predisposing factor for $C$. parapsilosis endocarditis $(41 / 72 ; 57.4 \%)$ involved prosthetic valves followed by IVD use $(12 / 72 ; 20 \%)$. Peripheral embolic and/or hemorrhagic events occurred in 28/64 (43.8\%) patients, mostly in cerebral and lower limb territories. Overall mortality was $41.7 \%$. Combined surgical and clinical
\end{abstract}

C. Garzoni and V. A. Nobre contributed equally to this manuscript.

The authors declare that there are no conflicts to disclose.

C. Garzoni · J. Garbino $(\bowtie)$

Division of Infectious Diseases, University Hospitals of Geneva,

24 Rue Micheli-du-Crest,

1211 Geneva 14, Switzerland

e-mail: jorge.garbino@hcuge.ch

C. Garzoni

e-mail: Christian.Garzoni@insel.ch

V. A. Nobre

Internal Medicine Division, Federal University of Minas Gerais, Rua Mirabela 424,

Belo Horizonte, Minas Gerais, Brazil

e-mail: vandack@medicina.ufmg.br treatment was associated with a lower mortality. Few patients received the newer antifungal agents, and it would appear that more experience is required for their use in the treatment of $C$. parapsilosis endocarditis.

\section{Introduction}

Although fungal endocarditis (FE) accounts for only 1.3-6\% of all infective endocarditis cases, it carries a high mortality risk and has increased in incidence over the last two decades $[1,2]$. The latter may be explained by improved diagnostic methods, a greater exposure to medical therapies that predispose to fungal infection, an increase in the incidence of intravenous drug (IVD) use and a more frequent use of invasive procedures for diagnosis and therapy $[1,3]$. Fungal endocarditis is associated with a higher incidence of embolic events than bacterial endocarditis. An additional diagnostic challenge is that some common clinical signs and symptoms of endocarditis, including the presence of cardiac murmurs, may be absent [4].

The incidence of invasive candidiasis has increased during the past years [5], with Candida species being the most common agents involved in fungal endocarditis, followed by Aspergillus species. In a review of 152 cases of FE, Candida spp. was responsible for $94.1 \%$ of yeast endocarditis and Aspergillus spp. for $71.8 \%$ of mold endocarditis [1]. Among yeast-related endocarditis, $C$. albicans was the most frequent strain isolated (46\%), followed by C. parapsilosis (17\%). The latter was the most common pathogen isolated in IVD users [4]. Candida parapsilosis is also associated with nosocomial infections related to vascular devices, which may be explained in part by its ability to produce a biofilm on foreign bodies and catheters [6]. 
We report here a case of relapsing C. parapsilosis endocarditis in an IVD user-patient and review the additional 71 cases published in the literature. A comparison of outcome differences with 52 C. albicans endocarditis cases was also conducted with the aim of identifying organism-specific clinical peculiarities.

\section{Materials and methods}

We conducted an OVID-MEDLINE search without language restriction from January 1968 through October 2006 to identify cases published in any language. The keywords "Candida parapsilosis", "endocarditis" and "fungal endocarditis" were used. Additional references were retrieved from reviews on the topic. Only reports with sufficient information on epidemiological and clinical data for patients over 16 years old were included. The review was also restricted to cases of "definite infective endocarditis" according to the modified Duke's criteria [7].

To evaluate potential clinical and epidemiological disagreement, the 72 cases of $C$. parapsilosis endocarditis were compared with 52 cases of $C$. albicans endocarditis recently reviewed [1].

Collected data were recorded in a database especially designed for the study. Analyses were performed by chisquare test, Fisher's exact test, and Student's $t$ test, as appropriate. Two-sided tests were used and $p<0.05$ was considered to be statistically significant. In the multivariate analysis, the dependent variable was mortality, and only variables with a $p<0.2$ in terms of outcome were included in a stepwise logistic regression model. Calculations were made using the EPIINFO statistical program, ver. 3.3.2 (Centers for Disease Control and Prevention, Atlanta, GA).

\section{Case report}

A 32-year-old man with a history of prior IVD use was hospitalized with acute thromboembolic stroke and $C$. parapsilosis candidemia. Transoesophageal echocardiography (TEE) revealed a 6-mm-sized floating vegetation in the aortic valve. In view of the intermediary susceptibility to fluconazole presented by the blood isolate of $C$. parapsilosis (MIC4 mg/l), combined therapy with caspofungin [70 mg intravenous (i.v.) as first day loading dose, followed by $50 \mathrm{mg}$ /day i.v.] and voriconazole [800 $\mathrm{mg}$ daily (p.o.) first day loading dose, followed by $400 \mathrm{mg} / \mathrm{d}$ p.o.] was administered for 12 weeks. The patient refused a surgical aortic valve replacement and was discharged with a proposed suppressive therapy of voriconazole $(400 \mathrm{mg}$ /day p.o), but was subsequently lost to follow-up. Three months after hospital discharge, he was re-hospitalized due to an episode of thromboembolic ischemic stroke linked to relapsed C. parapsilosis endocarditis. The patient acknowledged noncompliance to the voriconazole treatment previously prescribed. Voriconazole $(400 \mathrm{mg} /$ day p.o.) was restarted. A new TEE showed a vegetation in the aortic valve associated with a perforation and a mycotic aneurysm in the right coronary cuspid. A moderate to severe valve insufficiency was also found. In view of these findings and the severe hemodynamic compromise, the decision was taken to replace the aortic valve by a porcine xenograft valve (Schilling $\mathrm{N}^{\circ} 25$ ). The post-operative period was uneventful, and the patient was discharged from the hospital under voriconazole therapy ( $400 \mathrm{mg}$ /day p.o.) - and again was lost to follow-up. One year following surgery, the patient was re-admitted with severe cardiac failure due to severe aortic insufficiency associated with paravalvar leak. He admitted to having followed the antifungal treatment for only 4 months following his last discharge. Blood cultures yielded C. parapsilosis once again, and a TEE revealed vegetations in the aortic prosthetic valve. The patient died suddenly two days after admission. The authorization to perform the autopsy was not given.

\section{Results}

Including our own case, we retrieved a total of 80 cases of endocarditis due to C. parapsilosis. Of these, 72 met the inclusion criteria (Appendix). Most cases were published prior to the availability of the newer antifungal compounds, such as echinocandins and second-generation triazoles.

\section{Clinical presentation, risk factors and complications}

Of the 72 patients meeting the inclusion criteria of this review, $71 \%(51 / 72)$ were male, and the mean age was 48.73 years $( \pm 15.8$ years). Forty-one $(57 \%)$ patients had isolated prosthetic valve involvement, and $31(48.6 \%)$ had isolated native valve involvement; in four subjects, both native and prosthetic (relapsing infection) valve involvement occurred. Globally, the most frequent predisposing factor was prior cardiac surgery for valve replacement (57\%) (Table 1). Late-onset infection, defined here as 6 months following surgery, occurred in 21/33 (63.3\%) patients with prosthetic valve involvement for whom data were available. The second most frequent predisposing factor was IVD use (12/72 patients; $16.6 \%)$. Eleven of the 72 patients (15.2\%) presented simultaneously with more than one predisposing factor. An absence of predisposing factors was observed in only $4 / 72(5.6 \%)$ patients.

Data on embolic or hemorrhagic complications were available for $64(88.8 \%)$ of the 72 patients. Of these, 28 (43.8\%) presented complications, with the most common 
Table 1 Main predisposing factors, age, associated mortality rate and affected valves observed in 124 reported cases of Candida parapsilosis and C. albicans endocarditis ${ }^{\mathrm{a}}$

\begin{tabular}{|c|c|c|c|c|c|c|}
\hline & \multicolumn{2}{|c|}{ C. albicans } & \multicolumn{2}{|c|}{ C. parapsilosis } & \multirow[t]{2}{*}{ OR $(95 \% \mathrm{CI})$} & \multirow[t]{2}{*}{$p$ value } \\
\hline & $n$ & Percentage & $n$ & Percentage & & \\
\hline Number of patients & 52 & & 72 & & & \\
\hline \multicolumn{7}{|l|}{ Predisposing factors } \\
\hline Prosthetic valve & 29 & 55.8 & 41 & 57 & $0.95(0.4-2.0)$ & 0.94 \\
\hline IVD use & 4 & 7.7 & 12 & 16.6 & $0.42(0.1-1.5)$ & 0.23 \\
\hline Intravenous parenteral nutrition & 0 & 0.0 & 5 & 6.9 & $0(0-1.58)$ & 0.06 \\
\hline Broad spectrum antibiotics & 1 & 1.9 & 4 & 5.6 & $0.33(0-3.3)$ & 0.29 \\
\hline Abdominal surgery & 4 & 7.7 & 5 & 6.9 & $1.12(0.2-5.1)$ & 0.56 \\
\hline Previous valvular disease & 7 & 13.5 & 3 & 4.8 & $3.58(0.8-18.5)$ & 0.06 \\
\hline Immunosuppression $^{\mathrm{b}}$ & 5 & 9.6 & 4 & 6.4 & $1.81(0.4-8.6)$ & 0.30 \\
\hline Other & 3 & 5.6 & 3 & 4.1 & $1.41(0.2-9.2)$ & 0.49 \\
\hline None & 2 & 3.8 & 4 & 5.6 & $0.68(0.1-4.6)$ & 0.50 \\
\hline Mean age (years \pm SD) & 42.5 & 14.2 & 43.8 & 14.7 & - & - \\
\hline Mortality rate & 17 & 33 & 30 & 41.7 & - & - \\
\hline \multicolumn{7}{|l|}{ Valve } \\
\hline Aortic & 27 & 51.9 & 41 & 56.9 & - & - \\
\hline Mitral & 14 & 26.9 & 21 & 29.1 & - & - \\
\hline Tricuspid & 5 & 9.6 & 3 & 4.1 & - & - \\
\hline Combination & 6 & 11.5 & - & - & - & - \\
\hline Ventricular wall & - & - & 2 & 2.8 & - & - \\
\hline Pulmonary & - & - & 1 & 1.4 & - & - \\
\hline
\end{tabular}

OR, Odds ratio; 95\% CI, 95\% confidence interval; IVD, intravenous drug

${ }^{\mathrm{a}}$ More than one predisposing factor may be present for each patient

${ }^{\mathrm{b}}$ Includes one case of esophageal cancer, one case of allogenic bone marrow transplantation, one case of advanced HIV infection and to cases of diabetes

sites being the lower limbs (ten; 35.7\%) and the brain (six; $21.4 \%$ ), followed by the lung (three; $10.7 \%$ ) and the upper limbs (two; 7.1\%). Seven (25\%) of 28 patients presented intracranial hemorrhage, probably secondary to mycotic aneurysms.

Table 1 summarizes the characteristics of the 52 reported cases of $C$. albicans [1] and the 72 cases of $C$. parapsilosis endocarditis. The latter showed a trend towards a more frequent history of prior parenteral nutrition and valvular disease.

\section{Therapy and outcome}

Single, combined or sequential medical antifungal therapy was received by $28(38.0 \%), 25(34.7 \%)$ and $16(22.2 \%)$ patients, respectively. Amphotericin B deoxycholate was the most frequently prescribed antifungal drug in 41 patients $(56.9 \%)$, followed by 5 -fluocytosine (23 patients; $31.9 \%$ ) and fluconazole (20 patients; 27.7\%). Other antifungal treatments were lipid formulations of amphotericin B (six patients; 8.3\%) and miconazole and ketoconazole (five patients; 6.9\%). Five patients were treated with the newer antifungal drugs caspofungin (three patients; $4.1 \%$ ) and voriconazole (two patients; 2.7\%). Medical treatment was not specified in two cases $(2.7 \%)$. Combined surgical and medical treatment was performed in 42/72 $(58.3 \%)$ patients. Interestingly, surgical therapy was more commonly performed in native valve patients $(72.4 \%)$ than in patients with prostheses [45.7\%; Odds Ratio (OR) 3.1; 95\% confidence interval (CI) $1.0-8.9 ; p=0.05]$.

Neither mean age nor gender was associated with outcome. A trend was observed toward a higher mortality among patients with $C$. parapsilosis endocarditis less than 65 years (OR 3.18; 95\%CI 0.85-11.83; $p=0.07$ ). Of note, this was restricted to patients that underwent cardiac surgery (OR 5.2; 95\%CI 0.81-32.98; $p=0.08$ ).

The mortality rate was lower among patients undergoing adjunctive surgical therapy $(33.3 \%)$ than among those treated only with antifungals $(53.3 \%)$, but the difference was not statistically significant (OR 0.4 ; 95\%CI $0.2-1.1$; $p=0.14)$. Surgery was not related to a lower incidence of embolic and/or hemorrhagic complications, which were observed in $43.9 \%$ of surgical-associated therapy and $40.9 \%$ of the non-surgical cases (OR 1.1; 95\% CI 0.4-3.2; $p=0.96$ ). This result could be due to the higher incidence of embolic events in the early course of FE.

Even in a multivariate analysis adjusted for gender, age (two blocks; $\geq$ or $<$ than 65 years), combined surgical 
therapy or not and type of valve (native or prosthetic), an adjuvant surgical treatment was significantly associated with a better outcome (OR $0.3 ; 95 \%$ CI $0.1-1.0 ; p=0.05$ ) (Table 2).

\section{Discussion}

The first case of endocarditis due to $C$. parapsilosis was reported in 1940 [8]. In the years that followed, this agent was predominantly reported as an etiology of endocarditis, notably in IVD users [9]. However, C. parapsilosis is now considered to be an important emerging pathogen of invasive candidiasis, only surpassed by C. albicans [10], and this will probably have consequences on FE microbiology in the near future $[11,12]$. C. parapsilosis strains associated with invasive disease are more likely to produce biofilm structures [13] that are morphologically different from those produced by C. albicans [14].

Recent changes in fungal epidemiology may also be related to the wide use of azoles in combination with the new prophylactic and therapeutic strategies for fungal infections. More specifically, there is a consensus that the percentage of Candida non-albicans species accounting for nosocomial Candida infections is increasing, in part due to the widespread use of fluconazole [15]. The most probable source of infection in the outbreaks of $C$. parapsilosis infective endocarditis reported to date was determined to be intraoperative contamination (e.g. cardiac bypass equipment, tears in surgical gloves worn by carrier surgeons) $[16,17]$.

The core findings of this review reveal that the aortic valve was the most commonly involved valve, with $42.5 \%$ of cases occurring in native valves. The most common predisposing factor in patients with native valve involvement was IVD use. Overall mortality among these patients was as high as $41.7 \%$, with a lower mortality among those treated with adjuvant surgery. Only five cases treated with new antifungal drugs have been reported to date, which precludes the drawing of any firm conclusion on their role in the treatment of $C$. parapsilosis endocarditis.

Table 2 Variables associated with mortality in $64^{\mathrm{a}}$ patients presenting with endocarditis due to C. parapsilosis: multivariate analysis

\begin{tabular}{llll}
\hline & OR & $95 \%$ CI & $p$ value \\
\hline Age ( $\geq$ or $<65$ years) & 0.34 & $0.08-1.45$ & 0.14 \\
Gender & 1.0 & $0.29-3.39$ & 0.99 \\
Adjuvant surgery & 0.33 & $0.01-1.02$ & 0.05 \\
Type of valve (native or prosthetic) & 0.56 & $0.17-1.82$ & 0.34 \\
\hline
\end{tabular}

${ }^{a}$ Eight patients were excluded from the analysis: four patients without data on the type of involved valve and four patients with sequential native and prosthetic valve involvement
Only four $(5.7 \%)$ patients did not present any predisposing factor for C. parapsilosis endocarditis. However, Rubinstein and Lang reported that as high as $12 \%$ of patients presenting with FE have no identifiable predisposing factors [18]. In general, the predisposing factors observed were similar to those of patients with endocarditis due to C. albicans [19]. A comparison of C. albicans and C. parapsilosis endocarditis cases shows that $\mathrm{FE}$ due to these pathogens rarely originates without a predisposing factor and occurs more frequently in prosthetic valves. In addition, a history of IVD use was present in $20 \%$ of patients with $C$. parapsilosis infection. In contrast, $C$. albicans seems to be less frequently associated with IVD use and is observed predominantly in patients with underlying abnormal valves, mostly with rheumatic disease (Table 1). Our data suggest also that $C$. parapsilosis is more prevalent than C. albicans in patients receiving parenteral nutrition (Table 1).

Embolic and/or hemorrhagic complications were present in $43.8 \%$ of patients, most commonly as cerebral thromboembolic events, which is in accordance with the incidence rate reported by Ellis et al. [4]. In general, the occurrence of embolic events in patients with fever should always be seen as a potential diagnostic of infective endocarditis. In particular, a fungal etiology must be considered, given the high likelihood of thromboembolic events reported in these cases [20].

Survival in patients with FE is poor and barely exceeds 50\% [18]. Although C. parapsilosis endocarditis has been associated with a higher mortality when compared to endocarditis caused by other Candida species [19], this could not be confirmed in our comparison with C. albicans cases (Table 1).

The ideal treatment for Candida endocarditis has not been formally tested in prospective randomized controlled studies. In the present review, combined surgical and medical therapy was associated with a lower mortality rate. In clinical practice, surgery is generally regarded as the standard treatment for FE. The American College of Cardiology (ACC) and The American Heart Association (AHA) guidelines stipulate surgical indications for $\mathrm{FE}$ (Class I recommendation). In addition, the recent Infectious Diseases Society of America (IDSA) guidelines on Candida endocarditis recommend that it should be treated by valve replacement, either for native or prosthetic valves [21]. Unfortunately, the heterogeneity of the population affected, allied to the relative rarity of $\mathrm{FE}$, makes the performance of prospective studies impractical [4].

Retrospective studies based on well-documented cases may be a feasible alternative. In their recent meta-analysis, Steinbach et al. suggest that patients who underwent combined surgical and medical therapy may have presented a lower mortality rate (OR 0.56; 95\% CI 0.16-1.99). A higher 
mortality has been reported in patients infected by $C$. parapsilosis (OR 1.51; 95\%CI 0.39-5.52) and with leftsided endocarditis (OR 2.36, 95\%CI 0.55-10.07) [19]. However, methodological limitations should be considered when analyzing these results. For example, in very critically ill patients, a surgical procedure may be precluded, thus leading to a falsely higher mortality in the group with medical treatment alone. Moreover, a high number of patients with FE probably underwent surgery because endocarditis due to these agents are more frequently related per se to the classical indications for surgical treatment, such as thromboembolic events and the presence of large vegetations [22]. In the present review, thromboembolic events may have commonly indicated a surgical procedure, which explains why operated patients did not present a lower incidence of this complication in a cross-sectional analysis. Finally, isolated reports show that a single medical treatment for Candida endocarditis may be sufficient - in particular if the most potent and less toxic antifungal drugs are used [23].

We observed a lower mortality rate among patients that underwent adjuvant surgery. Multivariate analysis revealed that this tendency persisted even with adjustment for type of valve (native or prosthetic), gender and age ( $\geq$ or $<$ than 65 years). However, there was a lack of data for determining if patients treated with surgery had more severe disease and also on the delay between the diagnosis of endocarditis and the surgical procedure.

Since the mid-1990s, new antifungal drugs, such as second-generation triazoles (voriconazole and posaconazole), have become available which are well tolerated and active against fluconazole-less susceptible or fluconazoleresistant Candida species and which reach high body tissue concentrations, including in the central nervous system. Echinocandins (caspofungin, anidulafungin and micafungin), which have an innovative mechanism of action, are rapidly fungicidal for Candida species and are rarely associated with adverse events [24]. They present a good activity in the biofilm, which could be considered of interest in terms of FE in patients with prosthetic valves. Candida parapsilosis is less susceptible to echinocandins, but the clinical impact of the in vitro results have still to be evaluated [25]. However, apart from the lack of well-controlled clinical studies using these new compounds, high costs and the risk of resistance among fungal species are potential concerns for their widespread use. An early diagnosis allied to rapid and efficient treatment may potentially improve the outcome of FE.

This study presents some of the limitations that are common to retrospective studies. First, there is an important heterogeneity among included patients, and the clinical management of cases was not uniform. Second, data on patients treated with the new antifungal compounds are scarce, thus precluding any definitive conclusion. Finally, given that some of the relevant information is lacking in the reports, the retrospective analysis of treatments with the aim of comparing single medical or combined medical plus surgical treatment remains limited.

\section{Conclusions}

More experience is required with the use of newer antifungal agents in the treatment of $C$. parapsilosis endocarditis. These drugs may permit more efficient therapy since they are related to a higher efficacy and fewer side effects. As a result, the indication for surgical therapy may be reduced. Prospective randomized studies are required to answer these questions, although their feasibility is uncertain.

\section{Appendix}

Table 3 Details of 71 previously reported cases of Candida parapsilosis (1968-2006)

\begin{tabular}{|c|c|c|c|c|c|c|c|c|c|c|}
\hline Authors & Reference & Age & Gender $^{\mathrm{a}}$ & $\begin{array}{l}\text { Type } \\
\text { of } \\
\text { valve }^{b}\end{array}$ & Valve $^{c}$ & Predisposition $^{\mathrm{d}}$ & $\begin{array}{l}\text { Concomitant } \\
\text { surgery }\end{array}$ & Medical therapy ${ }^{\mathrm{e}}$ & Outcome & Complications \\
\hline $\begin{array}{l}\text { Abgueguen } \\
\text { et al. } 2002\end{array}$ & [1] & 81 & M & $\mathrm{P}$ & Ao & $\begin{array}{l}\text { Prosthetic } \\
\text { valve and } \\
\text { long-term } \\
\text { antibiotic } \\
\text { therapy and } \\
\text { abdominal } \\
\text { surgery }\end{array}$ & Yes & $\begin{array}{l}\text { Amp B }+ \\
\text { fluconazole }\end{array}$ & Dead & No \\
\hline $\begin{array}{l}\text { Aoyagi } \\
\text { et al. } 1989\end{array}$ & [2] & 56 & M & $\mathrm{N}$ & Mi and Ao & Absent & Yes & Unspecified drug & Survival & No \\
\hline $\begin{array}{l}\text { Auger } \\
\text { et al. } 1983\end{array}$ & [3] & 49 & M & $\mathrm{P}$ & $\mathrm{Mi}$ & $\begin{array}{l}\text { Prosthetic } \\
\text { valve }\end{array}$ & Yes & $\begin{array}{l}\text { Amp B, then } \\
\text { 5-FC }\end{array}$ & Survival & Ischemic stroke \\
\hline
\end{tabular}


Table 3 (continued)

\begin{tabular}{|c|c|c|c|c|c|c|c|c|c|c|}
\hline Authors & Reference & Age & Gender $^{\mathrm{a}}$ & $\begin{array}{l}\text { Type } \\
\text { of } \\
\text { valve }^{\text {b }}\end{array}$ & Valve $^{\mathrm{c}}$ & Predisposition $^{\mathrm{d}}$ & $\begin{array}{l}\text { Concomitant } \\
\text { surgery }\end{array}$ & Medical therapy ${ }^{\mathrm{e}}$ & Outcome & Complications \\
\hline Baddour 1995 & {$[4]$} & 45 & M & $\mathrm{P}$ & Ao & $\begin{array}{l}\text { Prosthetic } \\
\text { valve and } \\
\text { abdominal } \\
\text { surgery }\end{array}$ & No & $\begin{array}{l}\text { Amp B, then } \\
\text { Amp B lipidic } \\
\text { complex, then } \\
\text { fluconazole } \\
\text { (long-term } \\
\text { suppressive } \\
\text { therapy) }\end{array}$ & Survival & No \\
\hline $\begin{array}{l}\text { Blinkhorn } \\
\text { et al. } 1992\end{array}$ & {$[5]$} & 37 & M & $\mathrm{N}$ & Ao & IVD & Yes & $\begin{array}{l}\text { Valve } \\
\text { replacement } \\
\text { and } \\
\text { embolectomy } \\
\text { and Amp B + } \\
\text { 5-FC }\end{array}$ & Survival & $\begin{array}{c}\text { Lower limbs } \\
\text { embolism }\end{array}$ \\
\hline $\begin{array}{c}\text { Brandstetter and } \\
\text { Brause } 1980\end{array}$ & {$[6]$} & 24 & M & $\mathrm{N}$ & Ao & IVD & Yes & $\begin{array}{l}\text { Valve } \\
\text { replacement }+ \\
\text { mp B and 5-FC }\end{array}$ & Survival & No \\
\hline $\begin{array}{l}\text { Cancelas } \\
\text { et al. } 1994\end{array}$ & {$[7]$} & 35 & $\mathrm{~F}$ & $\mathrm{~N}$ & $\mathrm{Mi}$ & $\begin{array}{l}\text { Allogeneic } \\
\text { bone marrow } \\
\text { transplant }\end{array}$ & Yes & $\begin{array}{l}\text { Amp B, then } \\
\text { fluconazole } \\
\text { (twice) }\end{array}$ & Survival & No \\
\hline $\begin{array}{l}\text { Caparrós and } \\
\text { Cabrera } 2002\end{array}$ & {$[8]$} & 48 & M & $\mathrm{N}$ & Ao & $\begin{array}{l}\text { Long-term } \\
\text { antibiotic } \\
\text { therapy }\end{array}$ & Yes & $\begin{array}{l}\text { Embolectomy }+ \\
\text { liposomal } \\
\text { Amp B }\end{array}$ & Dead & $\begin{array}{c}\text { Lower limbs } \\
\text { embolism }\end{array}$ \\
\hline $\begin{array}{l}\text { Cheng and Yu. } \\
1970\end{array}$ & [9] & 29 & M & $\begin{array}{c}\mathrm{N} \text { and } \\
\mathrm{P}\end{array}$ & Mi and Tri & $\begin{array}{l}\text { Cardiac } \\
\text { surgery } \\
\text { Prosthetic } \\
\text { valve }\end{array}$ & Yes & $\begin{array}{l}\text { Valve } \\
\text { replacement }\end{array}$ & Dead & $\begin{array}{l}\text { Ischemic stroke } \\
\text { and pulmonary } \\
\text { embolism } \\
\text { (autopsy) }\end{array}$ \\
\hline Chuei-Shiun Li & {$[10]$} & 53 & M & $\mathrm{P}$ & Mi & $\begin{array}{l}\text { Diabetes } \\
\text { mellitus }\end{array}$ & Yes & Amp B & Survival & Ischemic stroke \\
\hline $\begin{array}{l}\text { Czwerwiec } \\
\text { et al. } 1993\end{array}$ & {$[11]$} & 58 & M & $\mathrm{P}$ & Ao & $\begin{array}{l}\text { Prosthetic } \\
\text { valve }\end{array}$ & No & $\begin{array}{l}\text { Amp B, then } \\
\text { fluconazole } \\
\text { (long-term } \\
\text { suppressive } \\
\text { therapy) }\end{array}$ & Survival & $\begin{array}{l}\text { Intracerebral } \\
\text { hemorrhage }\end{array}$ \\
\hline $\begin{array}{l}\text { Darwazah } \\
\text { et al. } 1999\end{array}$ & {$[12]$} & 67 & M & $\mathrm{P}$ & Ao & $\begin{array}{l}\text { Prosthetic } \\
\text { valve }\end{array}$ & Yes & $\begin{array}{l}\text { Valve } \\
\text { replacement }+ \\
\text { liposomal Amp } \\
\text { B and 5-FC }\end{array}$ & Survival & Ischemic stroke \\
\hline $\begin{array}{l}\text { De Belder } \\
\text { et al. } 1989\end{array}$ & {$[13]$} & 44 & M & $\mathrm{N}$ & Ao & $\begin{array}{l}\text { Ruptured } \\
\text { oesophagus } \\
\text { and } \\
\text { consequent } \\
\text { surgery }\end{array}$ & Yes & Amp B and 5-FC & Survival & Ischemic stroke \\
\hline $\begin{array}{l}\text { Diekema } \\
\text { et al. } 1997\end{array}$ & {$[14]$} & 79 & M & $P$ & Ao & $\begin{array}{l}\text { Prosthetic } \\
\text { valve }\end{array}$ & Yes & Amp B & Dead & No \\
\hline $\begin{array}{l}\text { Diekema } \\
\text { et al. } 1997\end{array}$ & [14] & 70 & M & $\mathrm{P}$ & Ao & $\begin{array}{l}\text { Prosthetic } \\
\text { valve }\end{array}$ & No & Amp B & Survival & No \\
\hline $\begin{array}{l}\text { Diekema } \\
\text { et al. } 1997\end{array}$ & [14] & 58 & M & $\mathrm{P}$ & Ao & $\begin{array}{l}\text { Prosthetic } \\
\text { valve }\end{array}$ & No & Amp B & Dead & No \\
\hline $\begin{array}{l}\text { Diekema } \\
\text { et al. } 1997\end{array}$ & [14] & 78 & M & $\mathrm{P}$ & Ao & $\begin{array}{l}\text { Prosthetic } \\
\text { valve }\end{array}$ & No & Amp B & Dead & No \\
\hline $\begin{array}{l}\text { Dismukes } \\
\text { et al. } 1973\end{array}$ & [15] & 47 & NR & $\mathrm{P}$ & Ao & $\begin{array}{l}\text { Prosthetic } \\
\text { valve }\end{array}$ & No & Amp B & Dead & NR \\
\hline
\end{tabular}


Table 3 (continued)

\begin{tabular}{|c|c|c|c|c|c|c|c|c|c|c|}
\hline Authors & Reference & Age & Gender $^{\mathrm{a}}$ & $\begin{array}{l}\text { Type } \\
\text { of } \\
\text { valve }^{b}\end{array}$ & Valve $^{\mathrm{c}}$ & Predisposition $^{\mathrm{d}}$ & $\begin{array}{l}\text { Concomitant } \\
\text { surgery }\end{array}$ & Medical therapy ${ }^{\mathrm{e}}$ & Outcome & Complications \\
\hline $\begin{array}{l}\text { Galgiani } \\
\text { et al. } 1977\end{array}$ & {$[16]$} & 36 & M & $\begin{array}{l}\mathrm{N} \text { and } \\
\mathrm{P}\end{array}$ & Ao & $\begin{array}{l}\text { Prosthetic } \\
\text { valve }\end{array}$ & $\begin{array}{l}\text { Yes } \\
\text { (three } \\
\text { times) }\end{array}$ & $\begin{array}{l}\text { Amp B, then } \\
\text { 5FC, then Amp } \\
\text { B }+5 F C\end{array}$ & Dead & No \\
\hline $\begin{array}{l}\text { Galgiani } \\
\text { et al. } 1977\end{array}$ & {$[16]$} & 50 & M & $\mathrm{P}$ & Aortic & $\begin{array}{l}\text { IVD and } \\
\text { prosthetic } \\
\text { valve }\end{array}$ & Yes (twice) & $\begin{array}{l}\text { Amp B, then } \\
\text { 5FC, then Amp } \\
\text { B and 5FC, } \\
\text { then miconazol }\end{array}$ & Dead & No \\
\hline $\begin{array}{l}\text { Garzoni } \\
\text { et al. } 2006\end{array}$ & NP & 32 & M & $\begin{array}{l}\mathrm{N} \text { and } \\
\mathrm{P}\end{array}$ & Aortic & $\begin{array}{l}\text { IDU and } \\
\text { ancient } \\
\text { abdominal } \\
\text { surgery }\end{array}$ & Yes & $\begin{array}{l}\text { Voriconazol and } \\
\text { caspofungin, } \\
\text { then } \\
\text { voriconazol }\end{array}$ & Dead & Ischemic stroke \\
\hline $\begin{array}{l}\text { Girmenia } \\
\text { et al. } 1996\end{array}$ & {$[17]$} & NR & NR & NR & NR & $\begin{array}{c}\text { Hematological } \\
\text { malignancy }\end{array}$ & No & $\begin{array}{l}\text { Amp B, then } \\
\text { fluconazole }\end{array}$ & Survival & NR \\
\hline $\begin{array}{l}\text { Girmenia } \\
\text { et al. } 1996\end{array}$ & {$[17]$} & NR & NR & NR & NR & $\begin{array}{l}\text { Hematological } \\
\text { malignancy }\end{array}$ & No & Fluconazole & Survival & NR \\
\hline $\begin{array}{l}\text { Gladstone } \\
\text { et al. } 1976\end{array}$ & {$[18]$} & 31 & M & $\mathrm{N}$ & Mitral & IVD & No & Amp B and 5-FC & Survival & $\begin{array}{c}\text { Lower limbs } \\
\text { embolism }\end{array}$ \\
\hline $\begin{array}{l}\text { Gomes } \\
\text { et al. } 1976\end{array}$ & [19] & 55 & M & $\mathrm{N}$ & Aortic & IVD & Yes & Amp B and 5-FC & Survival & No \\
\hline $\begin{array}{l}\text { Gottlieb } \\
\text { et al. } 1974\end{array}$ & {$[20]$} & 23 & M & $\mathrm{N}$ & Aortic & $\begin{array}{l}\text { IVD and } \\
\text { bicuspid } \\
\text { aortic valve }\end{array}$ & Yes & Amp B & Dead & $\begin{array}{l}\text { Intracerebral } \\
\text { hemorrhage }\end{array}$ \\
\hline $\begin{array}{l}\text { Grehl } \\
\text { et al. } 1972\end{array}$ & {$[21]$} & 51 & M & $\mathrm{P}$ & Aortic & $\begin{array}{l}\text { Prosthetic } \\
\text { valve }\end{array}$ & Yes (twice) & $\begin{array}{l}\text { Amp B , } \\
\text { then 5-FC } \\
\text { indefinitely }\end{array}$ & Survival & No \\
\hline $\begin{array}{l}\text { Herling } \\
\text { et al. } 1984\end{array}$ & {$[22]$} & 67 & $\mathrm{~F}$ & $\mathrm{~N}$ & Aortic & $\begin{array}{l}\text { Prosthetic } \\
\text { valve }\end{array}$ & Yes & $\begin{array}{l}\text { Valve } \\
\text { replacement }+ \\
\text { Amp B }\end{array}$ & Survival & No \\
\hline $\begin{array}{l}\text { Hoeprich } \\
\text { et al. } 1974\end{array}$ & {$[23]$} & 20 & $\mathrm{~F}$ & $\mathrm{~N}$ & Aortic & $\begin{array}{l}\text { IVD and } \\
\text { cardiac } \\
\text { surgery other }\end{array}$ & No & $\begin{array}{l}\text { 5-FC, then Amp } \\
\text { B and } \\
\text { clotrimoxazol }\end{array}$ & Dead & No \\
\hline $\begin{array}{l}\text { Inoue } \\
\text { et al. } 1998\end{array}$ & {$[24]$} & 57 & M & $\mathrm{N}$ & Aortic & $\begin{array}{l}\text { Parenteral } \\
\text { nutrition } \\
\text { chemotherapy } \\
\text { and } \\
\text { abdominal } \\
\text { surgery }\end{array}$ & Yes & Fluconazole & Survival & No \\
\hline $\begin{array}{l}\text { Isalska } \\
\text { et al. } 1988\end{array}$ & {$[25]$} & 37 & $\mathrm{~F}$ & $\mathrm{P}$ & Mitral & $\begin{array}{l}\text { Prosthetic } \\
\text { valve }\end{array}$ & No & $\begin{array}{l}\text { Amp B, then } \\
\text { Amp B and } \\
\text { 5FU, then } \\
\text { fluconazole }\end{array}$ & Survival & $\begin{array}{l}\text { Intracerebral } \\
\text { hemorrhage }\end{array}$ \\
\hline $\begin{array}{l}\text { Johnston } \\
\text { et al. } 1994\end{array}$ & [26] & 68 & M & $\mathrm{P}$ & Aortic & $\begin{array}{l}\text { Prosthetic } \\
\text { valve }\end{array}$ & No & $\begin{array}{l}\text { Amp B + 5-FC, } \\
\text { then } \\
\text { ketoconazole }\end{array}$ & Dead & NR \\
\hline $\begin{array}{l}\text { Johnston } \\
\text { et al. } 1994\end{array}$ & {$[26]$} & 41 & $\mathrm{~F}$ & $\mathrm{P}$ & Aortic & $\begin{array}{l}\text { Prosthetic } \\
\text { valve }\end{array}$ & No & Amp B & Dead & NR \\
\hline $\begin{array}{l}\text { Johnston } \\
\text { et al. } 1994\end{array}$ & [26] & 53 & M & $\mathrm{P}$ & Aortic & $\begin{array}{l}\text { Prosthetic } \\
\text { valve }\end{array}$ & No & Amp B + 5-FC & Dead & NR \\
\hline $\begin{array}{l}\text { Johnston } \\
\text { et al. } 1994\end{array}$ & [26] & 65 & M & $\mathrm{P}$ & Aortic & $\begin{array}{l}\text { Prosthetic } \\
\text { valve }\end{array}$ & No & $\mathrm{Amp} B+5-\mathrm{FC}$ & Dead & NR \\
\hline $\begin{array}{l}\text { Johnston } \\
\text { et al. } 1994\end{array}$ & [26] & 78 & $\mathrm{~F}$ & $\mathrm{P}$ & Aortic & $\begin{array}{l}\text { Prosthetic } \\
\text { valve }\end{array}$ & No & Amp B & Dead & NR \\
\hline $\begin{array}{l}\text { Jones } \\
\text { et al. } 2002\end{array}$ & {$[27]$} & 82 & M & $\mathrm{P}$ & Ao & $\begin{array}{l}\text { Prosthetic } \\
\text { valve }\end{array}$ & Yes & Amp B & Dead & $\begin{array}{l}\text { Lower and upper } \\
\text { limb embolism }\end{array}$ \\
\hline
\end{tabular}


Table 3 (continued)

\begin{tabular}{|c|c|c|c|c|c|c|c|c|c|c|}
\hline Authors & Reference & Age & Gender $^{\mathrm{a}}$ & $\begin{array}{l}\text { Type } \\
\text { of } \\
\text { valve }^{b}\end{array}$ & Valve $^{\mathrm{c}}$ & Predisposition $^{\mathrm{d}}$ & $\begin{array}{l}\text { Concomitant } \\
\text { surgery }\end{array}$ & Medical therapy ${ }^{\mathrm{e}}$ & Outcome & Complications \\
\hline $\begin{array}{l}\text { Jones } \\
\text { et al. } 2002\end{array}$ & {$[27]$} & 59 & $\mathrm{M}$ & $P$ & Ao & $\begin{array}{l}\text { Prosthetic } \\
\text { valve }\end{array}$ & Yes & $\begin{array}{l}\text { Amp B, then } \\
\text { liposomal Amp } \\
\text { B and 5-FC, } \\
\text { then } \\
\text { fluconazole }\end{array}$ & Survival & No \\
\hline $\begin{array}{l}\text { Kaloterakis } \\
\text { et al. } 2003\end{array}$ & {$[28]$} & 59 & M & $\mathrm{N}$ & Tri & $\begin{array}{l}\text { Parenteral } \\
\text { nutrition } \\
\text { antibiotic } \\
\text { therapy }\end{array}$ & Yes & $\begin{array}{l}\text { Liposomal Amp } \\
\text { B, then } \\
\text { fluconazole }\end{array}$ & Survival & No \\
\hline $\begin{array}{l}\text { Kontou- } \\
\text { Kastellanou } \\
\text { et al. } 1990\end{array}$ & [29] & 27 & M & $\mathrm{P}$ & Ao & $\begin{array}{l}\text { Prosthetic } \\
\text { valve }\end{array}$ & Yes & $\begin{array}{l}\text { Valve } \\
\text { replacement } \\
\text { and Amp B }\end{array}$ & Survival & No \\
\hline $\begin{array}{l}\text { Lejko-Zupanc } \\
\text { and Kozelj } \\
1977\end{array}$ & {$[30]$} & 62 & M & $\mathrm{P}$ & $\mathrm{Mi}$ & $\begin{array}{l}\text { Prosthetic } \\
\text { valve }\end{array}$ & No & $\begin{array}{l}\text { Amp B, then } \\
\text { fluconazole }\end{array}$ & Survival & No \\
\hline Li et al. 2004 & {$[10]$} & 53 & M & $\mathrm{N}$ & Ao & $\begin{array}{l}\text { Diabetes } \\
\text { mellitus and } \\
\text { dental } \\
\text { manipulation }\end{array}$ & Yes & Amp B & Survival & Ischemic stroke \\
\hline $\begin{array}{l}\text { Lipton } \\
\text { et al. } 1984\end{array}$ & {$[31]$} & NR & $\mathrm{F}$ & $\mathrm{N}$ & $\mathrm{Mi}$ & IVD & No & Amp B & Survival & $\begin{array}{l}\text { Intracerebral } \\
\text { hemorrhage }\end{array}$ \\
\hline $\begin{array}{l}\text { López-Ciudad } \\
\text { et al. } 2006\end{array}$ & {$[32]$} & 59 & $\mathrm{~F}$ & $\mathrm{~N}$ & $\begin{array}{l}\text { Ventricular } \\
\text { wall }\end{array}$ & $\begin{array}{l}\text { Abdominal } \\
\text { surgery } \\
\text { Parenteral } \\
\text { nutrition and } \\
\text { antibiotic } \\
\text { therapy }\end{array}$ & No & $\begin{array}{l}\text { Caspofungin and } \\
\text { voriconazole }\end{array}$ & Survival & No \\
\hline $\begin{array}{l}\text { Lozano } \\
\text { et al. } 1994\end{array}$ & {$[33]$} & 26 & M & $\mathrm{N}$ & Ao & IVD & Yes & $\begin{array}{l}\text { Fibrinolysis }+ \\
\text { Amp B and } \\
\text { 5-FC }\end{array}$ & Survival & $\begin{array}{l}\text { Lower limb } \\
\text { embolism }\end{array}$ \\
\hline $\begin{array}{l}\text { Martin } \\
\quad \text { et al. } 1979\end{array}$ & {$[34]$} & 30 & M & $\mathrm{N}$ & Ao & IVD & Yes & Amp B and 5-FC & Survival & No \\
\hline $\begin{array}{l}\text { Martin } \\
\text { et al. } 1987\end{array}$ & {$[35]$} & 67 & $\mathrm{~F}$ & $\mathrm{P}$ & Mi & $\begin{array}{l}\text { Prosthetic } \\
\text { valve }\end{array}$ & Yes & $\begin{array}{l}\text { Valve } \\
\text { replacement }+ \\
\text { Amp B, then } \\
\text { ketoconazole, } \\
\text { then } \\
\text { miconazole. }\end{array}$ & Dead & NO \\
\hline $\begin{array}{l}\text { Mayrer } \\
\text { et al. } 1978\end{array}$ & {$[36]$} & 43 & M & $\mathrm{N}$ & $\mathrm{Mi}$ & IVD & No & Amp B + 5-FC & Survival & No \\
\hline $\begin{array}{l}\text { Melgar } \\
\text { et al. } 1997\end{array}$ & {$[37]$} & 47 & M & $\mathrm{N}$ & Ao & Absent & Yes & $\begin{array}{l}\text { Amp B, then } \\
\text { ketoconazol, } \\
\text { then amp B, } \\
\text { then } \\
\text { fluconazole }\end{array}$ & Survival & No \\
\hline $\begin{array}{l}\text { Melgar } \\
\quad \text { et al. } 1997\end{array}$ & {$[37]$} & 47 & $\mathrm{~F}$ & $\mathrm{P}$ & $\mathrm{Mi}$ & $\begin{array}{l}\text { Prosthetic } \\
\text { valve }\end{array}$ & Yes & $\begin{array}{l}\text { Amp B, then } \\
\text { fluconazole }\end{array}$ & Survival & No \\
\hline Moudgal 2005 & {$[38]$} & 51 & M & $\mathrm{P}$ & Ao & $\begin{array}{l}\text { Prosthetic } \\
\text { valve }\end{array}$ & No & $\begin{array}{l}\text { Amp }+5 \text { FU, } \\
\text { then } \\
\text { caspofungin }+ \\
\text { fluconazole, } \\
\text { then Amp B } \\
\text { lipid complex }\end{array}$ & Survival & No \\
\hline
\end{tabular}


Table 3 (continued)

\begin{tabular}{|c|c|c|c|c|c|c|c|c|c|c|}
\hline Authors & Reference & Age & Gender $^{\mathrm{a}}$ & $\begin{array}{l}\text { Type } \\
\text { of } \\
\text { valve }^{b}\end{array}$ & Valve $^{c}$ & Predisposition $^{\mathrm{d}}$ & $\begin{array}{l}\text { Concomitant } \\
\text { surgery }\end{array}$ & Medical therapy & Outcome & Complications \\
\hline $\begin{array}{l}\text { Otaki and } \\
\text { Kitamura } 1993\end{array}$ & [39] & 55 & $\mathrm{~F}$ & $\mathrm{P}$ & Mi & $\begin{array}{l}\text { Prosthetic } \\
\text { valve }\end{array}$ & Yes & Fluconazole & Dead & $\begin{array}{l}\text { Intracerebral } \\
\text { hemorrhage }\end{array}$ \\
\hline $\begin{array}{l}\text { Record } \\
\text { et al. } 1971\end{array}$ & {$[40]$} & 57 & M & $\mathrm{P}$ & Ao & $\begin{array}{l}\text { Prosthetic } \\
\text { valve }\end{array}$ & No & $\begin{array}{l}\text { Amp B, then } \\
\text { 5FC }\end{array}$ & Dead & $\begin{array}{l}\text { Intracerebral } \\
\text { hemorrhage }\end{array}$ \\
\hline $\begin{array}{l}\text { Rubenstein } \\
\text { et al. } 1975\end{array}$ & [41] & 42 & M & $\mathrm{N}$ & Ao & No & Yes & Amp B & Dead & No \\
\hline $\begin{array}{l}\text { Rubenstein } \\
\text { et al. } 1975\end{array}$ & {$[41]$} & 17 & M & $\mathrm{N}$ & Mi & $\begin{array}{l}\text { Rheumatic } \\
\text { heart disease }\end{array}$ & Yes & Amp B & Dead & Ischemic stroke \\
\hline $\begin{array}{l}\text { Rubenstein } \\
\text { et al. } 1975\end{array}$ & [41] & 42 & M & $\mathrm{P}$ & Mi & IVD & No & Amp B and 5FU & Dead & $\begin{array}{l}\text { Intracranial } \\
\text { haemorrhage }\end{array}$ \\
\hline $\begin{array}{l}\text { Rubenstein } \\
\text { et al. } 1975\end{array}$ & {$[41]$} & 62 & $\mathrm{~F}$ & $\mathrm{~N}$ & Mi & $\begin{array}{l}\text { Cardiac } \\
\text { surgery other }\end{array}$ & No & Amp B & Dead & $\begin{array}{r}\text { Upper limb } \\
\text { embolism }\end{array}$ \\
\hline $\begin{array}{l}\text { Rubenstein } \\
\text { et al. } 1975\end{array}$ & {$[41]$} & 35 & $\mathrm{~F}$ & $\mathrm{~N}$ & Tri & $\begin{array}{l}\text { Rheumatic } \\
\text { heart disease }\end{array}$ & No & Amp B & Dead & $\begin{array}{l}\text { Pulmonary } \\
\text { embolism }\end{array}$ \\
\hline $\begin{array}{l}\text { Rudd } \\
\text { et al. } 1980\end{array}$ & {$[42]$} & 53 & $\mathrm{~F}$ & $\mathrm{P}$ & Ao & $\begin{array}{l}\text { Prosthetic } \\
\text { valve }\end{array}$ & Yes & Amp B & Survival & $\begin{array}{c}\text { Lower limb } \\
\text { embolism }\end{array}$ \\
\hline $\begin{array}{l}\text { Saito } \\
\text { et al. } 2001\end{array}$ & [43] & 72 & M & $\mathrm{N}$ & Tri & $\begin{array}{r}\text { Parenteral } \\
\text { nutrition }\end{array}$ & No & $\begin{array}{l}\text { Amp B and } \\
\text { fluconazole }\end{array}$ & Survival & No \\
\hline $\begin{array}{l}\text { Samelson } \\
\text { et al. } 1980\end{array}$ & [44] & 36 & $\mathrm{~F}$ & $\begin{array}{l}\mathrm{N} \text { and } \\
\mathrm{P}\end{array}$ & Mi & $\begin{array}{l}\text { Intervertebral } \\
\text { disc prosthetic } \\
\text { valve }\end{array}$ & Yes & $\begin{array}{l}\text { Different drug } \\
\text { therapies: Amp } \\
\text { B, 5-FC, } \\
\text { miconazole } \\
\text { and } \\
\text { ketoconazole }\end{array}$ & Survival & $\begin{array}{l}\text { Ischemic stroke, } \\
\text { cerebral } \\
\text { abscess, septic } \\
\text { thrombophlebitis }\end{array}$ \\
\hline $\begin{array}{l}\text { Senba } \\
\text { et al. } 1992\end{array}$ & {$[45]$} & 56 & M & $\mathrm{N}$ & Mi & No & Yes & $\begin{array}{l}\text { Valve } \\
\text { replacement }+ \\
\text { fluconazol and } \\
\text { miconazole }\end{array}$ & Survival & No \\
\hline $\begin{array}{l}\text { Severo } \\
\text { et al. } 1987\end{array}$ & {$[46]$} & 33 & M & $\mathrm{P}$ & Mi & $\begin{array}{l}\text { Cardiac } \\
\text { surgery } \\
\text { Prosthetic } \\
\text { valve }\end{array}$ & No & Ketoconazole & Dead & Ischemic stroke \\
\hline $\begin{array}{l}\text { Stulz } \\
\text { et al. } 1980\end{array}$ & {$[47]$} & 34 & $\mathrm{~F}$ & $\mathrm{P}$ & Mi & $\begin{array}{l}\text { Prosthetic } \\
\text { valve }\end{array}$ & Yes & Amp B & Survival & No \\
\hline $\begin{array}{l}\text { Sunazawa } \\
\text { et al. } 1995\end{array}$ & [48] & 42 & $\mathrm{~F}$ & $\mathrm{~N}$ & Pul & $\begin{array}{l}\text { Cardiac } \\
\text { surgery other }\end{array}$ & Yes & Unspecified drug & Survival & No \\
\hline $\begin{array}{l}\text { Tonomo } \\
\text { et al. } 2004\end{array}$ & [49] & 22 & M & NR & VW & $\begin{array}{l}\text { Abdominal } \\
\text { surgery } \\
\text { antibiotic } \\
\text { therapy and } \\
\text { parenteral } \\
\text { nutrition }\end{array}$ & Yes & $\begin{array}{l}\text { Miconazol, then } \\
\text { fluconazole } \\
\text { intercalated } \\
\text { with } \\
\text { miconazol. }\end{array}$ & Survival & $\begin{array}{l}\text { Pulmonary } \\
\text { embolism }\end{array}$ \\
\hline $\begin{array}{l}\text { Veraldi } \\
\text { et al. } 2000\end{array}$ & {$[50]$} & 29 & $\mathrm{~F}$ & $\mathrm{~N}$ & Ao & HIV infection & Yes & $\begin{array}{l}\text { Valve } \\
\text { replacement }+ \\
\text { surgical } \\
\text { embolectomy }+ \\
\text { Amp B } \\
\text { alternated with } \\
\text { fluconazole }\end{array}$ & Survival & $\begin{array}{c}\text { Lower limb } \\
\text { embolism }\end{array}$ \\
\hline $\begin{array}{l}\text { Vivas } \\
\text { et al. } 1985\end{array}$ & {$[51]$} & 54 & M & $\mathrm{N}$ & Mi & $\begin{array}{l}\text { Rheumatic } \\
\text { heart disease }\end{array}$ & No & Amp B & Dead & No \\
\hline $\begin{array}{l}\text { Wallbridge } \\
\text { et al. } 1993\end{array}$ & {$[52]$} & 58 & M & $\mathrm{P}$ & Mi & $\begin{array}{l}\text { Prosthetic } \\
\text { valve }\end{array}$ & No & $\begin{array}{l}\text { Amp B and 5FC, } \\
\text { then } \\
\text { fluconazole }\end{array}$ & Dead & No \\
\hline
\end{tabular}


Table 3 (continued)

\begin{tabular}{|c|c|c|c|c|c|c|c|c|c|c|}
\hline Authors & Reference & Age & Gender $^{\mathrm{a}}$ & $\begin{array}{l}\text { Type } \\
\text { of } \\
\text { valve }^{\text {b }}\end{array}$ & Valve $^{\mathrm{c}}$ & Predisposition $^{\mathrm{d}}$ & $\begin{array}{l}\text { Concomitant } \\
\text { surgery }\end{array}$ & Medical therapy ${ }^{\mathrm{e}}$ & Outcome & Complications \\
\hline $\begin{array}{l}\text { Wang } \\
\text { et al. } 1998\end{array}$ & {$[53]$} & 42 & $\mathrm{~F}$ & $\mathrm{~N}$ & Ao & $\begin{array}{l}\text { Cardiac } \\
\text { surgery other }\end{array}$ & Yes & $\begin{array}{l}\text { Fluconazole, } \\
\text { then Amp B, } \\
\text { then } \\
\text { fluconazole }\end{array}$ & Survival & $\begin{array}{c}\text { Lower limb } \\
\text { embolism }\end{array}$ \\
\hline $\begin{array}{l}\text { Watanakunakorn } \\
\text { et al. } 1968\end{array}$ & {$[54]$} & 40 & M & $\mathrm{P}$ & Ao & $\begin{array}{l}\text { Prosthetic } \\
\text { valve }\end{array}$ & Yes & Amp B & Dead & No \\
\hline $\begin{array}{l}\text { Zahid } \\
\text { et al. } 1994\end{array}$ & {$[55]$} & 48 & M & $\mathrm{P}$ & $\mathrm{Mi}$ & $\begin{array}{l}\text { Prosthetic } \\
\text { valve }\end{array}$ & No & $\begin{array}{c}\text { Amp B, then } \\
\text { 5-FC, then } \\
\text { fluconazole }\end{array}$ & Survival & No \\
\hline
\end{tabular}

NR, No report; NP, not published

${ }^{a} \mathrm{M}$, Male; F, female

${ }^{\mathrm{b}} \mathrm{N}$, Native; P, prosthetic

${ }^{c}$ AO, aortic; Mi, mitral; Tri, tricuspide; Pul, pulmonary; VW, ventricular wall

${ }^{\mathrm{d}} \mathrm{IVD}$, Intravenous drug use

${ }^{\mathrm{e}}$ 5FC, 5-fluocytosine; Amp B, amphotericine B

\section{References}

1. Pierrotti LC, Baddour LM (2002) Fungal endocarditis, 19952000. Chest 122(1):302-310

2. Horstkotte D, Follath F, Gutschik E, et al. (2004) Guidelines on prevention, diagnosis and treatment of infective endocarditis executive summary. Eur Heart J 25(3):267-276

3. Gottlieb S, Khuddus SA, Balooki H, et al. (1974) Echocardiographic diagnosis of aortic valve vegetations in candida endocarditis. Circulation 50(4):826-830

4. Ellis ME, Al Abdely H, Sandridge A, et al. (2001) Fungal endocarditis: evidence in the world literature, 1965-1995. Clin Infect Dis 32(1):50-62

5. Schelenz S, Gransden WR (2003) Candidaemia in a London teaching hospital: analysis of 128 cases over a 7-year period. Mycoses 46(9-10):390-396

6. Weems JJ Jr, Chamberland ME, Ward J, et al. (1987) Candida parapsilosis fungemia associated with parenteral nutrition and contaminated blood pressure transducers. J Clin Microbiol 25:1029-1032

7. Li JS, Sexton DJ, Mick N, et al. (2000) Proposed modifications to the Duke criteria for the diagnosis of infective endocarditis. Clin Infect Dis 30:633-638

8. Joachim M, Polayes S (1940) Subacute endocarditis and systemic mycosis (monilia). Mycoses 115(3):205

9. Rubinstein E, Noriega ER, Simberkoff MS et al. (1975) Fungal endocarditis: analysis of 24 cases and review of the literature. Medicine (Baltimore) 54(4):331-334

10. Weems JJ Jr (1992) Candida parapsilosis: epidemiology, pathogenicity, clinical manifestations, and antimicrobial susceptibility (see comments). Clin Infect Dis 14:756-766

11. Herling IM, Kotler MN, Segal BL (1984) Candida parapsilosis endocarditis without predisposing cause. Int J Cardiol 5(6):753756

12. Messer SA, Jones RN, Fritsche TR (2006) International surveillance of Candida spp. and Aspergillus spp: report from the SENTRY Antimicrobial Aurveillance Program (2003). J Clin Microbiol 44(5):1782-1787

13. Shin JH, Kee SJ, Shin MG et al (2002) Biofilm production by isolates of Candida species recovered from nonneutropenic patients: comparison of bloodstream isolates with isolates from other sources. J Clin Microbiol 40(4):1244-1248
14. Kuhn DM, Chandra J, Mukherjee PK, et al. (2002) Comparison of biofilms formed by Candida albicans and Candida parapsilosis on bioprosthetic surfaces. Infect Immun 70(2):878-888

15. Spellberg BJ, Filler SG, Edwards JE Jr (2006) Current treatment strategies for disseminated candidiasis. Clin Infect Dis 42(2): 244-251

16. Diekema DJ, Messer SA, Hollis RJ et al. (1997) An outbreak of Candida parapsilosis prosthetic valve endocarditis. Diagn Microbiol Infect Dis 29(3):147-153

17. Johnston BL, Schlech WF, Marrie TJ (1994) An outbreak of candida-parapsilosis prosthetic valve endocarditis following cardiac-surgery. J Hosp Infect 28(2):103-112

18. Rubinstein E, Lang R (1995) Fungal endocarditis. Eur Heart J $16: 84-89$

19. Steinbach WJ, Perfect JR, Cabell CH, et al. (2005) A metaanalysis of medical versus surgical therapy for Candida endocarditis. J Infect 51(3):230-247

20. Veraldi GF, Guglielmi A, Genna M, et al. (2000) Occlusion of the common iliac artery secondary of fungal endocarditis: report of a case. Surg Today 30(3):291-293

21. Rex JH, Walsh TJ, Sobel JD, et al. (2000) Practice guidelines for the treatment of candidiasis. Infectious Diseases Society of America. Clin Infect Dis 30(4):662-678

22. Habib G (2006) Management of infective endocarditis. Heart 92 (1):124-130

23. Lopez-Ciudad V, Castro-Orjales MJ, Leon C, et al. (2006) Successful treatment of Candida parapsilosis mural endocarditis with combined caspofungin and voriconazole. BMC Infect Dis $6: 73$

24. Dismukes WE (2006) Antifungal therapy: lessons learned over the past 27 years. Clin Infect Dis 42(9):1289-1296

25. Perlroth J, Choi B, Spellberg B (2007) Nosocomial fungal infections: epidemiology, diagnosis, and treatment. Med Mycol 45(4):321-346

References

1. Abgueguen P, Gouello JP, Pichard E, et al. (2002) Candida endocarditis: retrospective study in 12 patients. Rev Med Intern 23(1):30-40 
2. Aoyagi S, Kosuga K, Arita T, et al. (1989) A case report of successful surgical treatment of fungal endocarditis. Kyobu Geka 42(4):330-333

3. Auger PR, Pelletier LC, Dyrda I, et al. (1983) Endocarditis caused by Candida parapsilosis (para-krusei). Arch Mal Coeur Vaiss 76 (10):1231-1234

4. Baddour LM (1995) Long-term suppressive therapy for Candida parapsilosis-induced prosthetic valve endocarditis. Mayo Clin Proc 70(8):773-775

5. Blinkhorn RJ Jr, Eckhauser ML, Snow N (1992) Saddle embolism complicating Candida parapsilosis aortic valve endocarditis: cure with aortic valve replacement and prompt extraction of multiple mycotic emboli. J Vasc Surg 16(1):128-129

6. Brandstetter RD, Brause BD (1980) Candida parapsilosis endocarditis. Recovery of the causative organism from an addict's own syringes. JAMA 243(10):1073

7. Cancelas JA, Lopez J, Cabezudo E, et al. (1994) Native valve endocarditis due to Candida parapsilosis: a late complication after bone marrow transplantation-related fungemia. Bone Marrow Transplant 13(3):333-334

8. Castillo CA, Montijano Cabrera AM (2002) Candida parapsilosis endocarditis after prolonged antibiotic therapy. Rev Esp Anestesiol Reanim 49(4):209-212

9. Cheng S, Yu L (1970) Candida parapsilosis endocarditis following heart surgery: case report. Hawaii Med J 29(8):637-640

10. Li CS, Huang CR, Lu CH, et al. (2004) Concomitant stroke and Candida parapsilosis native valve endocarditis: report of one case and literature review. Acta Neurol Taiwan 13(3):131-135

11. Czwerwiec FS, Bilsker MS, Kamerman ML, et al. (1993) Longterm survival after fluconazole therapy of candidal prosthetic valve endocarditis. Am J Med 94(5):545-546

12. Darwazah A, Berg G, Faris B (1999) Candida parapsilosis: an unusual organism causing prosthetic heart valve infective endocarditis. J Infect 38(2):130-131

13. de Belder MA, Walker JD, Burnie JP, et al. (1989) Survival after rupture of the oesophagus and subsequent candidal endocarditis: use of new serological methods in management. Eur Heart J 10 (9):858-862

14. Diekema DJ, Messer SA, Hollis RJ, et al. (1997) An outbreak of Candida parapsilosis prosthetic valve endocarditis. Diagn Microbiol Infect Dis 29(3):147-153

15. Dismukes WE, Karchmer AW, Buckley MJ, et al. (1973) Prosthetic valve endocarditis. Analysis of 38 cases. Circulation 48(2):365-377

16. Galgiani JN, Stevens DA (1977) Fungal endocarditis: need for guidelines in evaluating therapy. Experience with two patients previously reported. J Thorac Cardiovasc Surg 73(2):293-296

17. Girmenia C, Martino P, De Bernardis F, et al. (1996) Rising incidence of Candida parapsilosis fungemia in patients with hematologic malignancies: clinical aspects, predisposing factors, and differential pathogenicity of the causative strains. Clin Infect Dis 23(3):506-514

18. Gladstone JL, Friedman SA, Cerruti MM, et al. (1976) Treatment of Candida endocarditis and arteritis. J Thorac Cardiovasc Surg 71 (6):835-838

19. Gomes JA, Calderon J, Lajam F, et al. (1976) Echocardiographic detection of fungal vegetations in Candida parasilopsis endocarditis. Am J Med 61(2):273-276

20. Gottlieb S, Khuddus SA, Balooki H, et al. (1974) Echocardiographic diagnosis of aortic valve vegetations in candida endocarditis. Circulation 50(4):826-830

21. Grehl TM, Cohn LH, Angell WW (1972) Management of Candida endocarditis. J Thorac Cardiovasc Surg 63(1):118-120

22. Herling IM, Kotler MN, Segal BL (1984) Candida parapsilosis endocarditis without predisposing cause. Int J Cardiol 5(6): 753-756
23. Hoeprich PD, Ingraham JL, Kleker E et al (1974) Development of resistance to 5-fluorocytosine in Candida parapsilosis during therapy. J Infect Dis 130(2):112-118

24. Inoue Y, Yozu R, Ueda T, et al. (1998) A case report of Candida parapsilosis endocarditis. J Heart Valve Dis 7(2):240-242

25. Isalska BJ, Stanbridge TN (1988) Fluconazole in the treatment of candidal prosthetic valve endocarditis. Br Med J 297(6642):178179

26. Johnston BL, Schlech WF III, Marrie TJ (1994) An outbreak of Candida parapsilosis prosthetic valve endocarditis following cardiac surgery. J Hosp Infect 28(2):103-112

27. Jones JM, Sarsam MA, Clarke MA et al (2002) Candida parapsilosis: two cases of endocarditis in association with the Toronto stentless porcine valve. J Infect 44(3):196-198

28. Kaloterakis A, Rizos I, Goumas G, et al. (2003) Isolated native tricuspid valve Candida endocarditis in a non-drug-addicted patient: case report and review of the literature. J Heart Valve Dis 12(5):652-658

29. Kontou-Kastellanou C, Leonardopoulos J, Boniatsi L, et al. (1990) A case of Candida parapsilosis endocarditis. Mycoses 33 (9-10):427-429

30. Lejko-Zupanc T, Kozelj M (1997) A case of recurrent Candida parapsilosis prosthetic valve endocarditis: cure by medical treatment alone. J Infect 35(1):81-82

31. Lipton SA, Hickey WF, Morris JH, et al. (1984) Candidal infection in the central nervous system. Am J Med 76(1):101-108

32. Lopez-Ciudad V, Castro-Orjales MJ, Leon C, et al. (2006) Successful treatment of Candida parapsilosis mural endocarditis with combined caspofungin and voriconazole. BMC Infect Dis 6:73

33. Lozano P, Flores D, Blanes I, et al. (1994) Acute lower limb ischemia complicating endocarditis due to Candida parapsilosis in a drug abuser. Ann Vasc Surg 8(6):591-594

34. Martin E, Pancoast SJ, Neu HC (1979) Candida parapsilosis endocarditis: medical and surgical cure. Ann Intern Med 91 (6):870-871

35. Alegre MJ, Gefaell de la Pena J, Planes Reig AM, et al. (1987) Late prosthetic endocarditis caused by Candida parapsilosis. Rev Esp Cardiol 40(3):215-216

36. Mayrer AR, Brown A, Weintraub RA et al (1978) Successful medical therapy for endocarditis due to Candida parapsilosis. A clinical and epidemiologic study. Chest 73(4):546-549

37. Melgar GR, Nasser RM, Gordon SM, et al. (1997) Fungal prosthetic valve endocarditis in 16 patients. An 11-year experience in a tertiary care hospital. Medicine (Baltimore) 76(2):94-103

38. Moudgal V, Little T, Boikov D, et al. (2005) Multiechinocandinand multiazole-resistant Candida parapsilosis isolates serially obtained during therapy for prosthetic valve endocarditis. Antimicrob Agents Chemother 49(2):767-769

39. Otaki M, Kitamura N (1993) Candida prosthetic valve endocarditis. An autopsy review. Int Surg 78(3):252-253

40. Record CO, Skinner JM, Sleight P et al (1971) Candida endocarditis treated with 5-fluorocytosine. $\mathrm{Br}$ Med J 1 (5743):262-264

41. Rubinstein E, Noriega ER, Simberkoff MS, et al. (1975) Fungal endocarditis: analysis of 24 cases and review of the literature. Medicine (Baltimore) 54(4):331-334

42. Rudd RM, Hill PR, Kopelman P, et al. (1980) Fungal endocarditis after homograft valve replacement: difficulties in diagnosis and treatment. Thorax 35(9):686-689

43. Saito Y, Takahashi M, Sato A, et al. (2001) Isolated tricuspid valve endocarditis due to Candida parapsilosis associated with long-term central venous catheter implantation. Intern Med 40 (5):403-404

44. Samelson LE, Lerner SA, Resnekov L, et al. (1980) Relapse of Candida parapsilosis endocarditis after long-term suppression 
with flucytosine: retreatment with valve replacement and ketoconazole. Ann Intern Med 93(6):838-839

45. Senba M, Watanabe K, Yoshida K, et al. (1992) Endocarditis caused by Candida parapsilosis. Southeast Asian J Trop Med Public Health 23(1):138-141

46. Severo LC, Alves AM, Bassanesi MC, et al. (1987) Endocarditis in biological prosthesis by Candida parapsilosis. Rev Inst Med Trop Sao Paulo 29(1):43-46

47. Stulz P, Hasse J, Mihatsch J, et al. (1980) Candida endocarditis after heart valve replacement (successful management with reoperation and local disinfection). J Cardiovasc Surg (Torino) 21(3):255-260

48. Sunazawa T, Uemura S, Fukuchi S, et al. (1995) A case report of acute pulmonary valve endocarditis caused by fungi. Nippon Kyobu Geka Gakkai Zasshi 43(1):74-77

49. Tonomo K, Tsujino T, Fujioka Y, et al. (2004) Candida parapsilosis endocarditis that emerged 2 years after abdominal surgery. Heart Vessels 19(3):149-152
50. Veraldi GF, Guglielmi A, Genna M, et al. (2000) Occlusion of the common iliac artery secondary of fungal endocarditis: report of a case. Surg Today 30(3):291-293

51. Romero VJ, Sanchez SA, Rodriguez CM et al (1985) Candida parapsilosis endocarditis. Med Clin (Barc ) 84(15):618-619

52. Wallbridge DR, McCartney AC, Richardson MD (1993) Fluconazole in the treatment of Candida prosthetic valve endocarditis. Mycoses 36(7-8):259-261

53. Wang JH, Liu YC, Lee SS (1998) Candida endocarditis following percutaneous transluminal coronary angioplasty. Clin Infect Dis 26(1):205-206

54. Watanakunakorn C, Carleton J, Goldberg LM, et al. (1968) Candida endocarditis surrounding a Starr-Edwards prosthetic valve. Recovery of candida in hypertonic medium during treatment. Arch Intern Med 121(3):243-245

55. Zahid MA, Klotz SA, Hinthorn DR (1994) Medical treatment of recurrent candidemia in a patient with probable Candida parapsilosis prosthetic valve endocarditis. Chest 105:1597-1598 